This is the authors' submitted manuscript. A final version of this article was published as: Susana Costa and Filipe Santos, Science \& Justice, https://doi.org/10.1016/j.scijus.2019.06.003

\title{
The social life of forensic evidence and the epistemic sub-cultures in an inquisitorial justice system: Analysis of Saltão case
}

\section{Susana Costa}

Filipe Santos

\section{Introduction}

Public discussions about forensic evidence and the criminal justice system have been largely centred on what Murphy called the "second generation of forensic science" [1]. In spite of the rapid development of DNA technologies for forensic identification and the paradigmatic changes it has brought about [2], traditional forensic science disciplines still represent important sources of information for criminal investigation.

This paper focuses on the case of the murder of an older woman, Laura, who was found dead in her home, in Coimbra, a city in the centre of Portugal. The investigation was quick in identifying a suspect. Ana Saltão, the only named suspect, was married to a grandson of the victim, both of them police inspectors at the Judiciary Police (PJ). ${ }^{1}$ She was detained one week after the crime and charged with Laura's murder.

A series of circumstances became the corner stone on the construction of the initial narrative that would be consolidated during the course of the investigation. The evidence that was brought to the proceedings highlighted the ways in which different epistemic cultures can produce alternative discourses about their respective probative value in the case.

Over the last few years, Saltão has been exonerated by a jury court, but convicted to 17 years in prison by a Court of Appeal. Later, the defence motioned the Supreme Court, which ordered a re-trial. The defendant was again acquitted. After a new ruling by the Court of

${ }^{1}$ In Portugal, the Judiciary Police (Polícia Judiciária) is the criminal investigation police responsible for serious crimes. 
Appeal, the first instance decision was upheld and Saltão was cleared from the murder charges under the in dubio pro reo principle.

The analysis of this case benefits from conceptual insights from studies of forensic science under a STS approach [3,4]. By adopting this perspective, this paper intends to contribute to advance knowledge of the socially constructed aspects of criminal investigation and penal justice. Appadurai's concept of "the social life of things" [5], which was later applied in Corinna Kruse's "the social life of forensic evidence" [6], highlights the ways in which objects and their social trajectories can be socially shaped. When studying the life and role of forensic evidence, according to Kruse, "this biography can be said to span the links of the legal chain, and it involves plaintiffs, suspects, witnesses, crime scene technicians, forensic scientists, police investigators, prosecutors, defense lawyer, judges, and lay assessors (...)" [6].

In the context of the criminal justice system, the social life of the forensic evidence can be infused with various meanings and weight according to the different epistemic cultures or cultures of knowledge [7]. Epistemic cultures are described by Knorr-Cetina as "amalgams of arrangements and mechanisms - bonded through affinity, necessity, and historical coincidence - which, in a given field, make up how we know what we know. Epistemic cultures are cultures that create and warrant knowledge" [7]. Therefore, the same crime can generate different stories, different narratives about what happened, according to the actors and epistemic cultures who intervene. In that sense, the criminal narrative assumes a "provisional

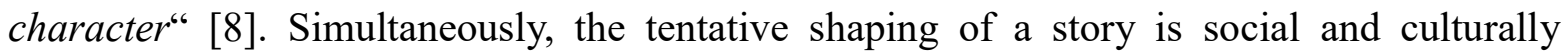
constructed.

\section{Travelling between epistemic cultures}

The narrative of the criminal investigation draws from previously established cultural and professional stock scripts $[9,10]$. For instance, homicide suspects are usually people close to the victim. Along their trajectory: "each piece of forensic evidence is a combination of the different epistemologies of which it has been a part during its social life" [6]. The police are the first elements in the chain of custody, being responsible for constructing the first narrative of the criminal event $[11,12]$. Their performance reflects in their own field but also in the different social and technical arenas [13]. 
The police forces assume a central task because everything they do will reflect on the life trajectories of the forensic evidence. The police are like "a spider in the web" [6], moving back and forth between different epistemic cultures. They contribute to the translation of the "evidence to be" [6] from the collection of traces to their framing within a criminal narrative. That is to say, "the production of forensic evidence is not finished until the verdict provides closure to both the case and the evidence" [6].

In adversarial systems, like in the UK or the USA, the disputing parties (the prosecution and the defence) present versions of the facts and access to resources and experts can be unequal [14]. Being an occasion for a confrontation between the representatives of the state and the accused, in which the evidence is discussed and deconstructed in court, there is a chance that errors or alternative interpretations of evidence will surface during the trial $[15,16]$. In inquisitorial legal systems, as is the case in Portugal (and most Western European countries), the judge "has disciplinary and administrative powers (...) and must ensure the exemption, objectivity and impartiality of the process" [8]. The judge plays an active role as "fact finder" and is regarded as the "experts of experts". ${ }^{2}$ Besides the crucial role of conducting the trial, he/she has to determine which pieces of evidence are admissible and evaluate them within the context presented.

Under inquisitorial proceedings, the Public Prosecution bears the burden of proof. It has the monopoly of criminal investigation and the power to initiate the necessary diligences, assisted by the police. Therefore, the prosecution receives information (or a criminal narrative) from the police about their investigative tasks and, subsequently, produces a legal narrative (or accusation) that is to be evaluated by a court [6]. Crucially, each of them has a different way of producing and recognizing knowledge. Prosecutors specialise in the assemblage of the forensic evidence by translating it to legal language. This means that they should distinguish between weak and strong evidence, as their role is to prosecute the defendant. In order to do this they have to highlight the strong evidence that demonstrates the actions of a suspect at a crime scene and minimise the relevance or absence of other evidence.

Between the police, the prosecution and the court, the forensic experts at the laboratory will transform the materiality of the traces into a scientific report, making "inherent uncertainties manageable" [6]. Nevertheless, these reports are usually expressed in ways that

\footnotetext{
${ }^{2}$ From the Latin expression judex est peritus peritorum. In the Portuguese Penal Process Code, this is implicit in Article 163, which states that the expert evidence is not subjected to free appreciation by the judge, and that if a judge disagrees with the expert, the reasons must be stated.
} 
remove the possibility of a direct legal translation of its results or conveying scientific answers to legal doubts [9]. They are placed at a hinged position between the crime scene and the court, mediating between the material and the symbolic. Being impossible for the experts to give a definitive answer or an absolute certainty, they can provide particular information about the likelihood of a given event. This probability will aid the court in drawing conclusions about the relations between the traces and the suspect's activities.

Over the following sections, we will briefly describe a murder case that constitutes an exemplary case of how the social life of forensic evidence and its biographies can inductively suggest the shaping of epistemic cultures. The successive movements and instances of interpretive flexibility [17] over the course of the judicial proceedings and the social life of forensic evidence draw the boundary lines of distinct epistemic cultures. We argue that these different cultures can be observed in a context of formal and apparent neutrality, from the Judiciary Police to the Courts.

The analysis of the trial and appreciation of evidence will not be so much about demonstrating the guilt or innocence of a given person, but on the confrontation of diverging interpretation of how knowledge about objects is produced and who has the authority to interpret them. The particular theoretical approach and analysis of the Saltão case should illuminate a typology of the different epistemic cultures involved in inquisitorial penal proceedings.

\section{Materials and Methods}

The materials for this paper were collected during the analysis of the Saltão Case, a homicide case judged in a Portuguese court. The Judge President of the Court of Coimbra and the President of the Appeal Court granted authorization for the consultation and use of the case proceedings under anonymity of all participants, except for the defendant. The analytical strategy was based on a qualitative grounded theory approach [18], in which the fully documented investigation and subsequent judicial proceedings were subjected to a recursive process of analysis, comparison, and categorisation, in order to extract significant and exemplary data. In addition, references on the interactions between the police and forensic laboratories in criminal cases that occurred in Portugal were also analysed as sources for comparison and contrast $[8,9,19,20]$. 
This paper aims to provide a better understanding of the multiple situated engagements of how the "evidence to be" is appropriated and co-constructed by different epistemic cultures of the judicial system. The innovative character of this paper lies in the emergence and characterization of different judicial sub-cultures highlighted in the Saltão case in relation to the production and interpretation of forensic evidence.

\section{The Saltão Case ${ }^{3}$}

Laura was found dead by her daughter, Júlia, her son-in law, António, and a neighbour. The victim was 80 years old and lived alone. Her body had been shot 14 times. The neighbours said that they heard loud noises around 16:00, but no one saw anyone enter or leave the building. The statements given by the relatives did not point to a likely suspect, considering that the victim had no enemies and had good family relations.

According to the PJ report, there was no evidence of theft or robbery, and the door did not appear to have been forced, which led the police to assume that "the motive of the crime was not objectively theft" suggesting a "proximity of the author" (849/12.1 JACBR, p. 11).

The PJ carried out a search in the home and vehicle of the daughter of the victim, but "nothing was found with interest to the case" (849/12.1 JACBR, p. 12). The PJ searched for traces of gunpowder residue on the victim's son, daughter and son-in-law. All tests were negative for gunpowder.

Ana Saltão and her husband Eduardo (grandson of the victim) lived more than $100 \mathrm{~km}$ away from Coimbra and both are police inspectors at the PJ - North Directorate. ${ }^{4}$ Three days after the crime, they were interviewed by the PJ. Saltão stated that the last time she saw Laura was in September and, on the day of the crime (21/11/2012), she left home around 10:00 to take her daughter to the nursery school, and picked her up again around 18:00. She had spent the day resting at home, because she had undergone a surgical intervention on 13/11/2012 on a tumour in her uterus.

\footnotetext{
${ }^{3}$ All elements in this paper that could identify individuals were changed to fictitious names and fictitious places in order to preserve the anonymity and confidentiality of the case. Only Ana Saltão is a real name as well as the name of the city where the crime occurred.

${ }^{4} \mathrm{PJ}$ is divided in three directorates: North, Centre and South Directorate. The crime occurred under the jurisdiction of the Centre Directorate and the suspect and her husband belong to the North Directorate.
} 
According to the PJ report, Eduardo said they were "experiencing financial difficulties" (849/12.1 JACBR, p. 80), having resorted to a loan from his grandmother which was being paid in monthly instalments. Eduardo also mentioned that Saltão had been in psychiatric care since November/2011 due to symptoms of depression and had been given medication. Eduardo said that she had been verbally abusive, calling him "dumb" and "disgusting" (849/12.1 JACBR, p. 80). Regarding his grandmother, Eduardo said that he did not know about the circumstances of the crime. Nevertheless, he told the police that he knew some important elements that might involve his wife (849/12.1 JACBR, p. 80).

On the day of the crime, he took the subway to work while Saltão stayed in bed. He talked to her on the phone around 9:45. He tried to call her during the afternoon of that day, but the phone was always off. When he got home Saltão "strangely enough, had not yet arrived" (849/12.1 JACBR, p. 81). Eduardo said that Saltão came home around 19:15/19:30. He questioned her about her phone being turned off, and she answered that a piece was broken and that it probably disconnected the phone. Eduardo did not notice any behavioural changes in his wife.

At night, when he was informed of his grandmother's death he travelled to Coimbra. On the next morning, on the way home, he made a call to his brigade chief and commented to him about the disappearance of a Glock firearm from the North Directorate of PJ. On the same day, the couple took their car and Eduardo noticed that the interior had been vacuumed and cleaned. When he asked her why the car was so clean, she explained that Eduardo's father had been in the car and could have contaminated it because he had been close to the body of the $\operatorname{victim}(849 / 12.1 \mathrm{JACBR}$, p. 82).

On the $25 / 11 / 2012$, the PJ made a search in the home of the couple. The records state that a long, dark grey coat, a pair of jeans, and a pair of black Nike shoes were collected.

On the next morning, when Saltão was at her parents' home, two officers asked her about the contents of the computer shared by the couple. In their report, the officers said that they noticed a wound on her right hand, and that Saltão said she had burned herself by touching a frying pan when cooking. She added that this was witnessed by her husband.

On the 28/11/2012, the PJ accessed a report dated from 8/11/2012 by Inspector Alice who worked in the same building and on the same floor as Saltão, informing about the disappearance of her firearm and clip with 14 rounds of ammunition from the drawer in her office desk. On the same day the PJ interviewed Saltão's neighbour Carla, who said that on 
the day of the crime she saw her in the entrance hall of their building between 14:15 and 14:30. Carla described Saltão as wearing a long dark coat and some sort of tracksuit type trousers and sneakers.

One week after the crime, a PJ report had considered Ana Saltão an official suspect (arguida), stating that: "there are several strong enough signs that point to Ana (...) as the material author of the crime" (849/12.1 JACBR, p. 175).

Based on the PJ's report, the Investigation and Penal Action Department of Coimbra (DIAP), the local branch of the Public Prosecution, detained Saltão and presented her to a judge who ordered that she remain under preventive custody. ${ }^{5}$ The DIAP began gathering surveillance data from a number of sources in order to obtain evidence of Saltão's movement on the day of the crime, namely highway tolls, mobile phone location and GPS history. The defendant's car had been seized in order to detect and to collect forensically relevant traces, particularly blood traces, but nothing relevant was found. The DIAP also ordered searches to Saltão and Eduardo's offices and personal computers, and requested bank statements from the accounts of the victim and her relatives, without significant results.

The victim's neighbours were interviewed. One of them - Isabel -, mentioned hearing the bells toll for 4 o'clock in the old tower of the University of Coimbra while she was talking on the phone. Isabel claims to have heard several loud noises around that time, but could not confirm how many.

On the 4/12/2012, the PJ informed the DIAP that there was a positive result from the forensic examination on Saltão's coat. The PJ also found particles of gunshot residue on the steering wheel of Saltão's car, which were similar to the residues in the bullet casings found at the crime scene and identical to the residues on the defendant's coat.

The evidence, or "strong signs" gathered by the PJ and presented by the DIAP led the judge to officially confirm the suspicion that Ana Saltão was the author of the crime and to hold her in preventive custody.

\subsection{PJ Narrative}

${ }^{5}$ Saltão spent 6 months in preventive custody. She was released on 17/05/2013, after which she was obligated to report every week to a police precinct. 
Very early on, one week after the crime, the PJ had made an evaluation of Saltão's culpability. Based on several circumstances that could potentially place her at the victim's house, a criminal narrative was initiated. This construction was possibly shaped by the fact that the suspect's husband was a police inspector, and also a friend and colleague of the inspectors responsible for the case. Saltão was the single suspect since the beginning of the investigation, mainly because of Eduardo's inquiry statement, his informal talks with his colleagues and the search made to Saltão's house. In a sort of investigative "tunnel vision" [21] the PJ built a narrative where the elements converge on Saltão as the likely author of the crime. First, the motive for the crime. The victim had lent $1.500 €$ to Ana Saltão and Eduardo. With the death of Laura, Saltão would stand to benefit from her husband's part in the inheritance. She had expressed "anguish" because the victim would not distribute her assets among the family. Furthermore, according to her husband, Ana Saltão was a compulsive spender, dealing poorly with financial limitations, which had been the cause of several fights between the couple, "even reaching occasions of threats, even death threats, curiously involving firearms (sic)” (849/12.1 JACBR, p. 176).

Second, the mens rea, or the criminal state of mind. Saltão was said to be under medical surveillance and treatment for depression "with a clinically complex picture" (849/12.1 JACBR, p. 177), a history of alcohol abuse, and having cold and calculating personality traits. She was also described in the report as displaying a disturbing dominance over her husband.

Third, there are the circumstances and opportunity for the crime. Since a colleague's weapon and a clip with 14 rounds of ammunition had disappeared from an office next to Saltão's, and the fact that there were 14 gunshots fired at the crime scene, the PJ assumed that the stolen weapon was "most likely the weapon used in crime" (849/12.1 JACBR, p. 175). Moreover, on the afternoon of the crime, Saltão's phone had been offline, and she thoroughly cleaned her car on the day after the crime.

\subsection{Public Prosecution Narrative}

In early 2014, the trial of the "Saltão case" started and the prosecution requested the intervention of the jury. ${ }^{6}$ The prosecution's narrative reproduces and adds further deductions

\footnotetext{
${ }^{6} \mathrm{~A}$ trial by jury can be requested by the defendant or the prosecution in cases that carry a potential sentence of more than 8 years in prison. This is not very common in Portugal and inquisitorial legal systems.
} 
that legitimise the narrative constructed by the PJ. Namely, the prosecution's narrative is more detailed in terms of providing a logical sequence to the alleged facts. Because the prosecution bears the burden of proof, their priority is to tell a story in a way that the argument resembles solid evidence. For example, and exhibiting a sort of "CSI Effect", ${ }^{7}$ the prosecution anticipates doubts because of a lack of material evidence. Therefore, the narrative to prosecute Saltão is based on her professional "forensic awareness" [22] to perpetrate the crime without leaving traces. Saltão's knowledge about the PJ's investigative tools and procedures appears as a narrative device that will explain and solve any doubts about the investigation and the apparent lack of evidence that can place the defendant at the crime scene.

The narrative constructed by the PJ was consolidated by the prosecution, leading the DIAP to accept it without reservations and taking the decision to arrest her. The following is an extract of the final Public Prosecution's report presented to the judge presiding over the case:

(...) At the beginning of the afternoon, Ana, wearing her long coat, drove her VW (...) and went to Coimbra (...). She had taken with her the Glock pistol and the clip she had taken from her colleague (...) with at least the 14 rounds of ammunition (...). She was careful to disconnect her mobile phone, knowing that she could be located if her mobile phone was switched on (...). In Coimbra, around 16:00, the defendant (...) took the pistol and, with her right hand, pointed it at Laura, discharging at least 14 shots towards the victim.

Because of the way in which she fired the weapon and the considerable number of shots, the slide of the pistol wounded the defendant in her right hand. After that, the defendant left the victim's house (...) she went to the place where the car was parked, and drove towards $\operatorname{Oliva}^{8}(\ldots)$

(...) The 14 shell casings were of $9 \mathrm{~mm}$ Parabellum calibre (9x19mm). All of these shells were triggered by the pistol that the defendant used, presenting class characteristics usually observed in ammunition discharged by Glock brand pistols. (...)

On 22/11/2012, Ana and Eduardo were contacted by the PJ in order to go to the North Directorate. (...) Before entering, the defendant was careful to clean the windows of the front doors of her car with towels. On the 25/11/2012, around 0:15, a PJ team went to the defendant's home where she was asked to deliver the clothes she had worn on the day of the homicide. Ana delivered to the PJ team the grey coat that she had worn when she killed her husband's grandmother, and did so because it did not show any visible trace that could connect her to the murder, a pair of blue jeans, and a pair of black Nike shoes (...). When these

\footnotetext{
${ }^{7}$ Cole and Dioso-Villa [34] argue that a variant of the so-called "CSI Effect", or the alleged influence of forensic science themed TV shows, has prosecutors changing their behaviour and compensating for the possibility that jurors may erroneously perceive the absence or weakness of forensic evidence. ${ }^{8}$ Fictitious city, corresponding to Saltão's city of residence.
} 
objects were examined in the LPC, it was found that only the coat had gunshot residues, (...) particles that were of the same type as detected in the shell casings that were collected at the crime scene.

On 26/11/2012 when the defendant was at her parents' house (...) the PJ went there to ask for the couple's computer (...). While handling it, Ana took care to pull her shirt sleeves down so that the hands were almost completely covered (...) in order to conceal the wound on her right hand, which had been caused by the slide of the Glock pistol used by her in the execution of the murder. (849/12.1 JACBR, p. $2777-$ 2786).

The extracts from the report quoted above employ a mixture of categorical assertions ("when she killed her husband's grandmother," or "the pistol that the defendant used"), with speculative remarks that relate to the defendant's forensically aware behaviour ("She was careful to disconnect the mobile phone,", "did so because it did not show any visible trace that could relate her to the murder").

The prosecution's narrative is mainly a legal device that legitimizes and reproduces the narrative drawn by the $\mathrm{PJ} .{ }^{9}$ Based on the postulate of neutrality, and assuming that the narrative constructed by the police is factual, the prosecution translates it into a legal narrative. Infused with rhetorical accuracy, it describes Saltão's every move on the day of the crime. Furthermore, in order to eliminate any uncertainty, the prosecution assumes that the part of the LPC's ${ }^{10}$ report where it says that the particles on her coat were "of the same type as the ones detected in the shell casings collected at the crime scene," is actually saying that they are come from the same source. The prosecution highlights the part of the report that fits with the police story, while rendering invisible ${ }^{11}$ alternative explanations or hypotheses that could affect the investigation.

The "forensic knowledge" of the defendant was initially appropriated by the prosecution to try to demonstrate how the crime could have been perpetrated without leaving traces. However, if Saltão's “forensic awareness" [22] is used by the prosecution to explain the absence of some evidence, and how the defendant almost escaped detection, this strategy does not explain why someone with extensive firearm experience would grip the weapon in such a manner as to cause a hand injury.

\footnotetext{
${ }^{9}$ The verbatim transposition of PJ reports into the prosecution's accusation and even to judicial sentences has been noted in other criminal cases, as observed by Santos [35].

${ }^{10}$ Laboratory of Scientific Police (Laboratório de Polícia Científica).

${ }^{11}$ See Costa, [24].
} 


\section{Narratives on Trial}

The trial started on June 2014. This was already a special case for several reasons: the defendant is a member of the PJ, there was significant media coverage, and it was a trial by jury. Most significantly, large parts of the proceedings were spent on the discussion and deconstruction of the forensic evidence. As previously stated, this is not common in inquisitorial justice systems.

The following analysis will focus on the three pieces of material evidence that were presented to the court, namely, the grey coat, the ammunitions and the hand injury sustained by Saltão. These traces allow us to show how the different actors understand the evidence in relation to the case. At the same time, they allow us to analyse not only the forensic knowledge brought to trial, but also the cognitive tensions between forensic notions of identification, individualization and uniqueness [23] that were often at play in the Saltão case.

\subsection{The grey coat}

The coat raised a number of relevant issues concerning the primary and secondary contamination and the procedure for collecting, recording and storing the evidence. Regarding the gunpowder residue found on the grey coat, the LPC reported that the particles found on the coat were of the same type as the ones found at the crime scene. This merely signifies that the particles share an identical chemical composition.

The characteristic/consistent particles detected in the shell casings obtained by the deflagration of the ammunition received in this laboratory (...) were of the same type as the particles detected in the grey coat (...) and the capsules collected at the crime scene (849/12.1 JACBR, p. 786).

Intentional or not, the prosecution interpreted the ballistics report as a scientific support to the notion that being of the "same type" was equivalent to saying that the gunpowder had the same source. For evidential purposes, the prosecution intended to establish that the gunpowder on the coat had "individual characteristics" that could be matched to the supposed crime weapon.

In an attempt to minimise the perceived weakness of the evidence, the police first, and later the prosecution, used the justification of the defendant's forensic awareness. Namely by arguing that Saltão had sufficient knowledge to perpetrate the crime and to eliminate the traces, as demonstrated in the prosecution's report regarding the coat. According to them, the only reason that Saltão delivered the coat was "because it did not show any visible trace that 
could connect her to the murder (...)." On the contrary, for the defence, Saltão delivered the coat because she was aware that, if she had committed the crime, the coat would have traces that could have incriminated her. Thus, an absence of gunpowder residue on that coat would exonerate her.

This comes to show that the argument of the defendant's professional knowledge or "forensic awareness" was appropriated by both the prosecution and the defence, to legitimise the evidence, but also to discredit its interpretation.

Since it was relevant to establish how the clothes were collected, Saltão was asked to talk about the search to her home when the objects were taken by the PJ:

Saltão - He [the PJ officer] did not collect anything. Then he finished the report and wrote - nothing of interest was found (...). We all signed the report, he packed his files in a black folder that he brought (...) and then he got up and told me:

- By the way... Do you remember what clothes you wore on the 21 st?

And I said: - Yes, I do. (...)

- And you can go get them?

Ok. So I went to the bedroom to get the jeans.

(...)

Saltão - And then I folded it all up and put them on the couch and said - Look, those are the clothes I was wearing that day. The sweater I cannot remember what it was... (849/12.1 JACBR, p. 3815)

This extract from the trial demonstrates Saltão's supposed forensic awareness insofar as she purposely allowed the officers doing the search to break protocol. During the trial, Saltão's defence raised doubts about the search made to her home. The chain of custody of all evidence gathered during that search could be invalidated since the defence revealed that it was Saltão herself who picked the trousers, sneakers and coat that was delivered to the officers. By treating Saltão as a colleague, who knew how to collect evidence, the PJ allowed the suspect to place potentially relevant traces together in a single supermarket plastic bag. This revelation led the prosecution to question the PJ inspector about it, who confirmed that the clothes were indeed delivered to them by Ana Saltão in a plastic bag, instead of a Police Evidence Bag (PEB).

PP - So she provided a plastic bag?

PJ Inspector - She provided a plastic bag where she placed and tied the sneakers, they were in the plastic bag. 
(...)

PJ Inspector - Yes, a plastic bag from the supermarket, yes. (849/12.1 JACBR, p. 3816)

This excerpt also illustrates the importance of the criminal narrative and how the evidence can be more or less relevant and, therefore, collected with more or less attention to protocol. In this case, since the likely suspect was already identified, in their view, the scientific evidence would "naturally" corroborate the established narrative. The container for the evidence or the chain of custody became of lesser importance in face of what seemed like an open and shut case, even if it was a supermarket bag.

This apparently circumstantial fact marked the inception of a defence narrative that worked towards undermining the prosecution's narrative by creating doubts about the evidence collection procedures in the case. The coat became a central piece in the discussion in order to understand the procedures that followed its delivery. The judge asked Saltão how she explained the existence of gunpowder particles on her coat, which she justified with probable contamination:

Judge $-(\ldots)$ How could this type of residue be found on your coat? (...)

Saltão - It could only have been from contamination. Because... (849/12.1 JACBR, p. 3816)

When Saltão was given authorization to access the case files, she realised the possible mishandling of evidence. Because she was a PJ inspector herself, she could recognize the floor of her colleagues' office at the Coimbra Directorate, where she noticed that her coat had been photographed. The prosecution then asked the PJ Inspector to describe the procedures used to document the coat as evidence.

PP - Did you put some paper, any tissue (cloth) under the material, sir?

PJ Inspector - No. Nor was that available in the Directorate. (849/12.1 JACBR, p. 3780)

Again, this excerpt shows the sociocultural understandings made by the police [24], who considered it relevant to photograph the coat, but neglect important details such as the care to avoid contamination by placing a paper under the coat. ${ }^{12}$ The inspector felt the need to explain that such materials were not available in their facilities. The focus of the police work relied on the support of the previously established narrative, assuming that photographing the objects is sufficient to show the relation between the defendant, the coat, and the crime.

${ }^{12}$ Privileged informants say that this is a normal procedure in the PJ's daily work. 
The issue is further complicated with the interpretation of the laboratory results. Besides the potential secondary or tertiary ${ }^{13}$ contamination problems caused by photographing the coat on a surface where there are people that use firearms, there were problems with the notions of identification and individualization [23]. ${ }^{14}$

The police and the prosecution tried to demonstrate that there was gunpowder residue on the coat because the defendant fired the murder weapon. The defence was arguing that there were some particles on the coat because it was photographed on a contaminated surface.

Nevertheless, the LPC report stated that the gunpowder particles found on the coat were compatible with shot(s) fired from a weapon, manipulation of, or proximity to the firing(s) of a firearm. The report also indicated that the particles detected in the coat were of the same type as those that are found in the type of ammunition used in the murder weapon. The alternative transfer mechanisms suggested in the LPC report were not considered by the police or the prosecution, and the defence used this to question an expert about the chain of custody of the coat:

Defence - What is the way to get the material for analysis?

LPC Expert - The best way is each piece in each bag. But, since all the pieces are referenced as being from the same person, there was no reason to refuse the analysis.

Defence - What if, for example, the clothes had been worn in different situations?

LPC Expert - This would have to be analysed by the investigation. (849/12.1 JACBR, p. 3933)

The defence intentionally tried to establish the boundaries of the work done by the laboratory and the work done by others. The expert's evasive answer avoided responsibility for the evidence's delivery or storage conditions, while asserting that it was not the prescribed procedure.

The defence continued this line of questioning by summoning an expert consultant from the National Institute of Legal Medicine and Forensic Sciences (INMLCF), the other institute that is authorized to perform forensic analysis in Portugal. The aim was to discredit the connection made in the police narrative between the coat, the firearm, and the crime. Now, the

\footnotetext{
${ }^{13} \mathrm{As}$ French and Morgan argue [36], there are concrete possibilities of gunshot residue (GSR) indirect transfer, either by secondary (e.g. shaking hands with a person who discharged a weapon), tertiary (shaking hands with a person that shook the hand of a person who discharged a weapon), and even radial deposition mechanisms (standing in the vicinity of a person who discharged a weapon). Therefore, there is a great potential for misinterpretation that calls for the consideration of alternative transfer mechanisms.

${ }^{14}$ See also Cole, 2009; Dror \& Charlton, 2006; Saks \& Koehler, 2008.
} 
focus was on the police procedure and not on the analysis or interpretation of the traces. The defence asked an INMLCF expert to clarify if photographing a coat on the floor was a correct procedure:

INMLCF Expert - If it is a clean room, there is no contamination. If it is a contaminated room, then it could not be ruled out that there is contamination [on the coat]. (...) The proper procedure [is] to put it on a sheet of paper.

Defence - And not on the floor? (...) Would you have made the examination if you had known about it?

INMLCF Expert - It is not the proper procedure. (849/12.1 JACBR, p. 3937)

The social life of forensic evidence is marked by instances boundary work [25] regarding their construction. The experts assert their impartiality but, nevertheless, affirm that there is a proper and correct forensic procedure to handle evidence. If the experts' task is to do the analyses, it does not necessarily mean that they are aware of the non-scientific trajectories of the items prior to their entrance to the laboratory. Thus, the technicians and the experts can only assume responsibility for the traces from the moment they enter the laboratory, and for the respective reports.

\subsection{Gunshot residue (GSR)}

Concerning the GSR, one of the arguments used by the PJ and the prosecution was that the $9 \mathrm{~mm}$ ammunitions were exclusively employed by the PJ. The calibre of the Glock that was reported missing from the office of Saltão's colleague and the calibre of the murder weapon were also $9 \mathrm{~mm}$. With that in mind, the prosecution asked an inspector about the ammunition in his own service weapon in order to reinforce the idea that the crime was committed with a PJ service weapon. The defence called for the testimony of the LPC's expert in order to question the prosecution's associations between the particles on the coat and the weapon:

Defence - (...) examining these particles, is it possible to know the calibre, or the weapon that fired them?

LPC Expert - No, it is not. Only what I said in the report is possible. To say that they are of the same type. (849/12.1 JACBR, p. 3935)

Remitting questions to the forensic reports can be seen as the scientists' boundary work. It is also a way to preserve neutrality and leave interpretations for the court. By stating that the particles are of the same type, the expert is saying that they belong to a given population (identification), but they cannot be ascribed with individual characteristics. 
Aware of this flaw in the prosecution's narrative, the defence further explored the impossibility of individualization of the gunshot residue, and even the type of weapon.

Defence - Saying that is a Glock, or is it a Walther, or an HK, or any other, is strictly the same?

LPC Expert - Is not relevant. (849/12.1 JACBR, p. 3938)

The traditional principles of forensic science identification have been based on the notion that it is possible to trace an unknown mark to a unique source [26]. The shortcomings and exaggerated claims surrounding some types of forensic evidence have been established and documented $[2,27,28]$. In the Saltão case, the court was presented with the two competing narratives about the GSR evidence. The police and prosecution versions hold that there is identity between the GSR found on Saltão's coat, the stolen Glock from Saltão's colleague, and Laura's murder. The defence started the deconstruction of the GSR evidence beginning with the collection and documentation procedures, and closing by pointing out the impossibility of the individual identification of the source of the GSR in the coat.

\subsection{Hand Injury}

Regarding the injury on Saltão's hand, the INMLCF report indicated:

Presence of scarring vestiges, (...) with characteristics that lead us to admit that it may have been produced by an instrument of a forceful nature or acting as such. However, it is not possible to completely exclude the action of a possible thermal agent (burn by incandescent object contact, with a week of evolution) (849/12.1 JACBR, p. 123).

Previously, the PJ narrative had interpreted the injury on Saltão's hand as fitting into the scenario where she used the missing Glock to commit the murder. The prosecution followed the police's deduction that the injury was indeed caused by the slide of the weapon on Saltão's hand. However, the expert's report did not exclude some other thermal agent to be the cause of the injury. When questioned by the defence, another expert confirmed the interpretation provided by the report where Saltão's explanation that she burnt herself making an omelette was also plausible.

The narrative of the trial itself was shaped by the confrontation of the police and prosecution's versions against the alternative interpretation of the presented evidence. Several experts were called to testify and provide clarifications, not only about the evidence collection procedures, but most importantly, about the limits of the role that the evidence can play in the narratives. 


\subsection{The verdict}

All crime narratives and the social life of forensic evidence converge towards a verdict. With the advantage of perspective, the judge and jury evaluate the narratives and the presented evidence. The trial exposed the problems with the investigation and the case against Saltão: failure to adhere to adequate forensic procedure, concealment of evidence, and the potentially damaging interference of personal relationships in the course of the investigation.

The court's verdict reinterpreted the police and prosecution's narratives in light of the facts that emerged during the trial. The defendant's financial situation was not a credible motive and it was not proven that she suffered from any serious psychiatric disorder, as the court found that these were "mere assumptions" (849/12.1 JACBR, p. 3701) made by the investigation.

As for the timeline of the crime, it was established during the trial that it occurred between 15:45 and 16:19. However, there was a testimony from Saltão's neighbour that testified to have met her in the lobby of their building around 14:30. This was regarded as an important and credible testimony, which was omitted when the defendant was interrogated at the DIAP (849/12.1 JACBR p. 3710).

Regarding the GSR that was found on the coat, the expert report stated that there was no clear association between the residue on the coat and direct exposure to the discharge of a firearm. The possibility of indirect contamination could not be excluded. ${ }^{15}$ Besides the defendant's professional occupation as a PJ inspector, "the investigation has inexplicably and against all the rules governing a police investigation - laid out the coat on the floor of the PJ office, compromising the probative value of the expert conclusions" (849/12.1 JACBR, p. 3720). Furthermore, the police put two pieces of clothing and a pair of sneakers "in the same PEB bag". This "incomprehensible oversight" could have "irreparably" compromised the preservation of the chain of custody in relation to one of the strongest pieces of evidence on which the charge was based (849/12.1 JACBR, p. 3720).

The jury doubted that the Glock was stolen from the office of Saltão's colleague and that the same weapon was used in the crime. The PJ did not start an investigation about the missing weapon and there was no evidence that could link Saltão to it. In this sense, the

\footnotetext{
${ }^{15}$ To explore a review of GSR contamination issues, see Blakey, Sharples, Chana, \& Birkett, 2018.
} 
coincidence between the missing Glock and the murder weapon and ammunition was not judged sufficient to infer that the weapon and ammunition used in the murder were stolen and used by Saltão. During the trial, an LPC expert testified that the type of firearm used in the murder is commonly found on the black market or easily acquired on the internet. Additionally, Saltão's hand injury that was interpreted in the PJ narrative as being caused by the slide of the Glock, could also be explained by contact with a thermal agent like a hot frying pan. The medical expert who testified at the trial hearing said that such an injury was not typical of poor firearm handling. Although such possibility cannot be fully excluded, Saltão is trained in the use of firearms and the Glock is regarded, ergonomically, as a very safe weapon.

The material evidence was constructed in the investigation to fit a particular chain of circumstances, events and timeline. However, the trial also revealed inconsistencies in the circumstantial evidence. Given that a neighbour met Saltão around 14:30 and the crime occurred between 15:45 and 16:19, Saltão would have to have travelled more than 120 kilometres (about 1h30m), plan for traffic and parking, and be sure that the victim would be at home and alone. The phone bill provided by a witness who heard the shots, Laura's neighbour, indicates that the phone call that she mentioned as having occurred at 16:00 started at 15:16, which makes it unlikely that Saltão managed to drive to Coimbra at the indicated time. This document was omitted by the police. The fact that the defendant was medicated at the time of the crime would impair her mobility and dexterity, at the same time it would lend credibility to her version that she stayed home resting.

Consequently, the jury was convinced that the case carried a great deal of complexity that transcended what was discussed in the proceedings, considering that "the likelihood of the accused having committed the crimes attributed to her is very low," adding that neither was it possible to be certain that Saltão did not commit the crimes (849/12.1 JACBR, p. 3722). Invoking the principle of in dubio pro reo, the jury acquitted the defendant (849/12.1 JACBR, p. 3722).

The subsequent appeal by the prosecution was favoured by a May 2015 Appeal Court decision that sentenced the defendant to 17 years in prison. The sentence of the Appeal Court argued that evidence other than forensic evidence should be valued and that the trial was not about seeking a scientific truth. In this sense, according to the Appeal Court, the doubts that emerged during the trial and acquitted Saltão cannot be grounded on scientific issues. 
The Appeal Court sentence motivated an appeal to the Supreme Court (SC). Contrary to the Appeal Court, the SC considered that the arguments presented by the AC are not sufficient to establish the defendant's culpability. Ana Saltão's actions cannot be causally linked to the crime because there were missing relevant facts to the decision, which must be stated. Therefore, the Supreme Court ordered a new trial of Ana Saltão because more evidence was needed. The re-trial, which took place in 2017, found the defendant not guilty, motivating another appeal by the prosecution. The case reached an end on the 9 January 2019 with the AC acquitting the defendant, invoking the principle of in dubio pro reo.

\section{Discussion}

The Saltão case is exemplary in bringing to the fore how different epistemic cultures assess, value, and interpret the same scientific evidence. The way in which this particular case was investigated and put on trial illuminates the socio-cultural biases that affect how knowledge in particular settings and contexts can be constructed.

In the Saltão case, what appears to be clear is that the weight of the evidence was differentiated according to professional roles and epistemic cultures. For some, the narrative is made stronger by the evidence, even if the evidence is weak. Others argue that the narrative does not make sense if it is not validated by scientific evidence. This case comes to show that scientific evidence, as an epistemic object, can be instrumental to reveal or conceal information depending on the paradigm or epistemic culture that guides the search for knowledge in the context of law.

The analysis of the investigation and the trial of the Saltão case allowed the construction of a typology of several "cultures", brought forth from the frictions between the different epistemic cultures that contribute to the social life of forensic evidence.

A hunch culture that illustrates a narrative-based investigation. These tend not to be drawn from the evidence alone but on repertoires of "stock scripts" [10] moulded by professional experience and perceptions of typified criminal behaviour [9]. The hunch culture is often found in the police and it is prominent in cases where the efforts to collect evidence from crime scenes are trumped by apparently fitting stories of a chain of events and their actors.

While this type of culture can be observed in police work, it tends to affect the prosecution. Although the Public Prosecution is the entity responsible for conducting the 
criminal investigation in Portugal, the early steps and decisions in a criminal investigation are often undertaken by police inspectors. The assumed impartiality of the judicial services tends to hinder a more proactive role by the prosecution, creating an environment where their contribution is to frame the police narratives into legal storytelling. What could be called a cabinet culture of the prosecution is thus grounded on the police's intuitions about the crime, without direct knowledge of the crime scene. From a distanced point of view, the prosecution's role is to use legal language to support and lend credibility to the police's hunches. The argument of the "rules of experience" is often used to assert certainty where forensic evidence does not offer definitive answers and is open to interpretation. For instance, the result that there were GSR on Saltão's coat was interpreted as to lend "scientific" credibility to the story where Saltão killed Laura with the gun missing from her colleague's office. This prosecution could only reach this conclusion because Saltão's husband had already raised suspicion over her. The scientific evidence brought to the case seemed to have just an instrumental use, that is, to provide a sense of scientific authority to the previously constructed narrative. In this sense, the scientific evidence was sought as a means to confirm the ongoing narrative, instead of being the basis for its construction. The culture and context generated by the police and the prosecution puts forensic technicians and experts in tension with the need to preserve neutrality and the boundaries of scientific activities [25,29]. As illustrated in the Saltão case, but already documented in other studies [9,24,30,31,32]), the perceived hermetic character of the science contributes to a bubble culture characterized by the experts' enactment of a kind of "laboratorial sterilisation" in judicial contexts. The experts' bubble culture is expressed in defensive attitudes when they testify about forensic evidence, like repeating the discursive formulae of the forensic reports, or making general statements about laboratory procedures. Mainly, the experts avoid ruptures in their "shield of neutrality" by circumventing replies that could be understood by the courts as interpretation of the evidence in their context. Since testifying in court is part of the experts' profession, the bubble culture could be seen as a way to protect the experts from the evidential work done upstream (selection, collection, handling, an early interpretation by the police) and downstream (ultimately, by the judge who has the responsibility to interpret the evidence).

\section{Conclusion}

The Saltão case offers a good example of the sociocultural and institutional frameworks that shape criminal investigation and the criminal justice system in Portugal, with plausible 
replication in other inquisitorial justice systems. While the police trusts science's contribution to the investigation, its use tends to be more instrumental to serve a given narrative than to offer confirmation or clues to other avenues of investigation. Confronted with the experts' bubble culture, the hunch culture of the police has difficulty in fitting results that do not corroborate the established narrative. Therefore, the police interpretation of results may ultimately either serve the narrative or remain underexplored.

It is noteworthy that a murder case like the Saltão case did not produce any biological traces as evidence. Even without biological traces, the forensic evidence brought to this case highlighted the understandings and practices of the investigation and the weight attributed to the evidence by different cultures. Moreover, it is interesting that the narrative constructed by the police and by the prosecution, although unconsciously, has tried to align the scientific discourse from the area of ballistics with matters of identification and individualization that are often surround the discussion of DNA evidence [37].

The analysis of Saltão case showed how the "evidence to be," can be resurrected over and over again. The social life of the forensic evidence, in the same way, could never end too. One explanation for this can be found in the different understandings that different epistemic cultures build regarding the evidence. If the different epistemic cultures were articulated, the story would be different. Certainty about Saltão's guilt or innocence could be achieved and the "evidence to be" could have reached an end. More importantly, a critical assessment of the trajectories of the evidence by Saltão's defence managed to avoid a conviction and a potential miscarriage of justice.

\section{Acknowledgements}

The authors would like to express their gratitude to the Judge President of the Court of Coimbra and to the Appeal Court President who granted authorisation for the consultation and use of the research materials. 


\section{Funding}

This research was co-funded by the Portuguese Foundation for Science and Technology and by European funds (COMPETE and POCH - European Social Fund) under the Strategic Project CES-UID/SOC/50012/2013, the post-doctoral fellowship SFRH/BPD/108667/2015, and the individual contracts DL57/2016/CP1341/CT0004 and CEECIND/03932/2017.

\section{References}

[1] E. Murphy, The new forensics: Criminal justice, false certainty, and the second generation of scientific evidence, Calif. Law Rev. 95 (2007) 721-797.

[2] M.J. Saks, J.J. Koehler, The coming paradigm shift in forensic identification science, Science. 309 (2005) 892-895.

[3] S. Jasanoff, Just evidence: The limits of science in the legal process, J. Law, Med. Ethics. 34 (2006) 328-341. doi:10.1111/j.1748-720X.2006.00038.x.

[4] S. Jasanoff, Science at the bar. Law, science, and technology in America, Harvard University Press, Cambridge, MA and London, UK, 1995.

[5] A. Appadurai, ed., The social life of things. Commodities in cultural perspective, Cambridge University Press, Cambridge, 1986. doi:10.1016/j.ajem.2009.07.023.

[6] C. Kruse, The social life of forensic evidence, University of California Press, Oakland, CA, 2016.

[7] K. Knorr-Cetina, Epistemic cultures. How the sciences make knowledge, Harvard University Press, Cambridge, MA; London, UK, 1999.

[8] F. Santos, Crime, narrativa e DNA: Os desafios da prova de DNA no processo inquisitorial [Crime, narrative and DNA: The challenges of DNA evidence in inquisitorial proceedings], Lex Humana. 9 (2017) 40-67. http://seer.ucp.br/seer/index.php/LexHumana/article/viewFile/1444/675.

[9] F. Santos, Making sense of the story: The dialogues between the police and forensic laboratories in the construction of DNA evidence, New Genet. Soc. 33 (2014) 181-203. doi:10.1080/14636778.2014.916186.

[10] C. Kruse, Legal storytelling in pre-trial investigations: Arguing for a wider perspective on forensic evidence, New Genet. Soc. 31 (2012) 299-309. 
http://www.tandfonline.com/doi/abs/10.1080/14636778.2012.687084 (accessed August 2, 2012).

[11] M. Lynch, S. Cole, R. McNally, K. Jordan, Truth machine: The contentious history of DNA fingerprinting, University of Chicago Press, Chicago, 2008.

[12] R. Williams, DNA databases and the forensic imaginary, in: R. Hindmarsh, B. Prainsack (Eds.), Genet. Suspects Glob. Gov. DNA Profiling Databasing, Cambridge University Press, Cambridge, 2010: pp. 131-152.

[13] D. Wyatt, Accomplishing technical and investigative expertise in everyday crime scene investigation, University of Exeter, 2014.

[14] J. Vuille, Admissibility and appraisal of scientific evidence in continental European criminal justice systems: Past, present and future, Aust. J. Forensic Sci. 45 (2013) 389397. doi:10.1080/00450618.2012.738248.

[15] M. Lynch, S. Jasanoff, Contested identities: Science, law and forensic practice, Soc. Stud. Sci. 28 (1998) 675-686. doi:10.1177/030631298028005001.

[16] M. Lynch, Contested identities - The discursive production of uncertainty: The OJ Simpson 'Dream Team' and the sociology of knowledge machine, Soc. Stud. Sci. 28 (1998) 829-868.

[17] S.L. Star, This is not a boundary object: Reflections on the origin of a concept, Sci. Technol. Hum. Values. 35 (2010) 601-617. doi:10.1177/0162243910377624.

[18] K. Charmaz, Constructing grounded theory: A practical guide through qualitative analysis, SAGE Publications, Thousand Oaks, CA, 2006.

[19] S. Costa, A justiça em laboratório: A identificação por perfis genéticos de ADN. Entre a harmonização transnacional e a apropriação local, Almedina, Coimbra, 2003.

[20] F. Santos, As funções do DNA na investigação criminal: Estudo de cinco casos em Portugal, in: H. Machado, H. Moniz (Eds.), Bases Dados Genéticos Forenses Tecnol. Control. e Ordem Soc., Coimbra Editora, Coimbra, 2014: pp. 197-228.

[21] M.L. Radelet, H.A. Bedau, C.E. Putnam, In spite of innocence: Erroneous convictions in capital cases, Northeastern University Press, Boston, 1994.

[22] E. Beauregard, M. Bouchard, Cleaning up your act: Forensic awareness as a detection avoidance strategy, J. Crim. Justice. $38 \quad$ (2010) 1160-1166. 
doi:10.1016/j.jcrimjus.2010.09.004.

[23] D.H. Kaye, Identification, individualization and uniqueness: What's the difference?, Law, Probab. Risk. 8 (2009) 85-94. doi:10.1093/lpr/mgp018.

[24] S. Costa, Visibilities, invisibilities and twilight zones at the crime scene in Portugal, New Genet. Soc. 36 (2017) 375-399. doi:10.1080/14636778.2017.1394835.

[25] T.F. Gieryn, Boundary-work and the demarcation of science from non-science: Strains and interests in professional ideologies of scientists, Am. Sociol. Rev. 48 (1983) 781795.

[26] M.J. Saks, J.J. Koehler, The individualization fallacy in forensic science evidence, Vanderbilt Univ. Law Rev. 61 (2008) 199-219. doi:10.1016/j.forsciint.2004.07.005.

[27] I.E. Dror, D. Charlton, Why experts make errors, J. Forensic Identif. 56 (2006) 600-616.

[28] M.J. Saks, D.L. Faigman, Failed forensics: How forensic science lost its way and how it might yet find it, Annu. Rev. Law Soc. Sci. 4 (2008) 149-174. doi:10.1146/annurev.lawsocsci.4.110707.172303.

[29] R.K. Merton, The sociology of science: Theoretical and empirical investigations, University of Chicago Press, Chicago, 1973.

[30] S. Costa, H. Machado, J.A. Nunes, O ADN e a justiça: A biologia forense e o direito como mediadores entre a ciência e os cidadãos, in: M.E. Gonçalves (Ed.), Os Portugueses. e a Ciência, Dom Quixote, Lisboa, 2003: pp. 200-223.

[31] H. Machado, F. Santos, Popular press and forensic genetics in Portugal: Expectations and disappointments regarding two cases of missing children, Public Underst. Sci. 20 (2011) 303-318. doi:10.1177/0963662509336710.

[32] H. Machado, S. Costa, Biolegality, the forensic imaginary and criminal investigation, Rev. Crit. Cienc. Sociais. 5 (2013) 84-105. http://rccsar.revues.org/490.

[33] P. Gill, Analysis and implications of the miscarriages of justice of Amanda Knox and Raffaele Sollecito, Forensic Sci. Int. Genet. 23 (2016) 9-18. doi:10.1016/j.fsigen.2016.02.015.

[34] S.A. Cole, R. Dioso-Villa, CSI and its effects: Media, juries, and the burden of proof, New Engl. Law Rev. 41 (2007) 435-470.

[35] F. Santos, Genética forense, justiça e média em Portugal: Elementos de co-produção 
num estudo de cinco casos criminais, Universidade do Minho, 2015. http://repositorium.sdum.uminho.pt/handle/1822/36678.

[36] J. French, R. Morgan, An experimental investigation of the indirect transfer and deposition of gunshot residue: Further studies carried out with SEM-EDX analysis, Forensic Sci. Int. 247 (2015) 14-17. doi:10.1080/09593985.2016.1206155.

[37] S. Cole, Forensics without uniqueness, conclusions without individualization: The new epistemology of forensic identification, Law, Probab. Risk. 8 (2009) 1-23. doi:10.1093/lpr/mgp016.

[38] L.S. Blakey, G.P. Sharples, K. Chana, J.W. Birkett, Fate and behavior of gunshot residue - A review, J. Forensic Sci. 63 (2018) 9-19. doi:10.1111/1556-4029.13555. 